\title{
Mediumship: review of quantitatives studies published in the 21 st century
}

\author{
Marco Aurélio Vinhosa Bastos Jr.1, Paulo Roberto Haidamus de Oliveira Bastos¹, Lídia Maria Gonçalves², \\ Igraíne Helena Scholz Osório2, Giancarlo Lucchetti ${ }^{3}$
}

- Universidade Federal de Mato Grosso do Sul (UFMS) - Programa de Pós-Graduação em Saúde e Desenvolvimento na Região Centro-Oeste, Campo Grande, MS, Brazil.
2 UFMS - Faculdade de Medicina, Campo Grande, MS, Brazil.

${ }_{3}$ Universidade Federal de Juiz de Fora (UFJF) - Núcleo de Pesquisa em Espiritualidade e Saúde, Juiz de Fora, MG, Brazil.

Received: 6/30/2015 - Accepted: 10/8/2015

DOl: 10.1590/0101-60830000000063

\begin{abstract}
Background: Mediumship can be defined as the alleged ability to communicate with deceased persons. The last decade has been particularly productive for this field of research and the study of mediumship can help the understanding of the human mind-brain relationship and provide objective data to the scientific community and to the general population. Objective: The aim of this review is to summarize and discuss the results found on recent studies investigating mediumship. Furthermore, we aim to discuss the psychophysiology underlying mediumship and future perspectives for this study topic. Methods: A literature search for articles in English, Portuguese and Spanish published from January 2000 up to June 2015 was conducted using three electronic databases (PubMed, Lilacs and Web of Science). Review articles, qualitative studies and studies investigating altered states of consciousness caused by psychoactive substances were excluded. The original search returned 150 articles, but the application of exclusion criteria resulted in the inclusion of 19 articles for final analysis. Results: The general findings were: (1) an association of mediumship with good mental health, predominantly in experienced mediums, (2) heterogeneous findings regarding the ability of mediums to provide accurate information what may be due to different study methodologies and (3) incipient studies assessing physiological correlations during mediumistic communications (i.e. hypoactivation of brain regions responsible for cognitive processing and writing planning during psychography compared to a control task; electroencephalographic (EEG) changes and a slight predominance of the sympathetic nervous system). Discussion: There is a paucity of empirical data available in this controversial research field. New studies employing rigorous design (e.g. triple-blind protocols to test accuracy of mediumistic communications), and sensitive methods are required.
\end{abstract}

Bastos Jr. MAV et al. / Arch Clin Psychiatry. 2015;42(5):129-38

Keywords: Mediumship, after-death communication, spiritual experiences, mental health, psychophysiology.

\section{Introduction}

Although there is no formal consensus on the definition of mediumship, it could be roughly defined as the alleged ability to communicate with deceased personalities on a regular basis ${ }^{1}$, or as a set of experiences in which an individual, alleged "medium", maintains regular contact or stays under the control of someone else who has already died or of another immaterial being2.

At different times and among different cultures in human History there were reports of experiences that could be interpreted as mediumistic phenomena, for example the reception of the Ten Commandments by Moses at the Mount Sinai (Christianity and Judaism) and the reception of information and advice from superior and protector beings (dharmapalas) by Tibetan Buddhist monks ${ }^{3}$.

During the $19^{\text {th }}$ century and in the early $20^{\text {th }}$ century, many pioneers of modern Psychology and Psychiatry have studied cases of alleged mediums. This was the case of William James, who for many years studied the medium Leonora Piper4; Pierre Janet, who wrote a book about the "psychological automatism"5; Carl G. Jung, who received his doctorate degree after studying his cousin (S.W.), an alleged medium ${ }^{6}$, among others. At that time, other renowned scientists also dedicated their time and effort to study mediumistic phenomena, such as William Crookes ${ }^{7}$ and Charles Richet ${ }^{8}$.

Talking to "spirits" or being possessed by "spirits" are cultural phenomena found in almost every society worldwide and their relationship with mental illness has been the topic of extensive investigations in the fields of cross-cultural psychiatry and anthropology $y^{9,10}$. Observational studies demonstrate a high prevalence (around 80 percent) of individuals who believe in the survival of the soul after death in general population ${ }^{11,12}$, and this finding is congruent with the significant popularity that many cultural products covering this topic have (e.g.: books, films, novels, TV series) ${ }^{13}$.
At present, mediumship is considered to be a form of dissociation $^{14,15}$. Dissociation can be defined as "the occurrence of experiences and behaviors that are thought to exist apart from, or to have been disconnected from, the mainstream of one's conscious awareness, behavioral repertoire, and/or self-concept" 16 . The majority of culture-bound dissociation is considered normal, does not lead to distress or impairment, it often arises in willing individuals in appropriate (frequently religious) contexts, and is usually experienced as beneficial. In subjects with pathologic dissociation, the experiences occur in an unsolicited, unruly and socially nontolerated manner, causing considerable distress, with adverse effects on occupational activities and other impairments ${ }^{17}$.

Many societies where culture-bound dissociation is observed are characterized by an authoritarian male hierarchy, being oppressive for women and children. Some scholars affirm that in many of these societies, the dissociative experiences are more common in women and they propose that dissociation would be a psychological mechanism with an emotion-regulatory role. This is seen as a socially sanctioned (and even valued) behavior that would allow cathartic expression of forbidden and disowned feelings by individuals living under characteristically oppressive conditions ${ }^{14,17}$.

Self-hypnosis is one of the proposed psychophysiological mechanisms involved in dissociation. After carefully analyzing mediumship in the context of Candomblé, an Afro-Brazilian religion, Seligman (2005) ${ }^{14}$ concluded that mediums would be individuals with a psychophysiological tendency to somatization and to dissociation that, submitted to emotional distress, find in the religion system (and in the assumption of a new social role as mediums) a way for a positive transformation of their identities, leading to a moderation of their somatic and emotional afflictions and to a global therapeutic effect ${ }^{14,17}$.

Much of the controversy surrounding mediumship research derives from de fact that it stresses the "mind-brain problem"18. The explanation for how the human brain generates mind is one of the 
greatest philosophical and scientific challenges of the past, the present, and probably of the future ${ }^{19}$. The French seventeenth century philosopher René Descartes put forth the theory of Substance Dualism, supporting the idea that mind (subjective) and body (objective) are different natural substances and that it is the bond of mind to the brain that allows it to think. Mind and brain being independent entities, consciousness could continue to exist (and perhaps communicate) despite the death of the physical body. On the other hand, the dominant materialist perspective argues that consciousness is a byproduct of brain activity, being extinguished with the death of the physical body. A better understanding of mind could only be possible through an increase on the knowledge about brain functioning 20-22.

Contemporary dualist philosophers and scientists sustain that materialism has left a range of questions unanswered, as, for example, how human subjective and affective experiences exert such a decisive influence over body functions. For many dualist and post-materialist scientists the evidences stemming from high quality studies about near-death experiences and about mediumistic communication are strong indicators that consciousness has a non-local character and could survive the death of the physical body ${ }^{19}$.

Currently, the three most common explanations for mediumship are: (1) fraud (conscious or unconscious), (2) after-death communication, and (3) telepathy. The first, the materialist model, excludes the possibility that any aspect of the personality can survive physical death and rejects extra-sensorial perceptions (ESP) in general. Thus, if a mediumistic information seems accurate this can only result of deliberate fraud, coincidence or "cold reading" (fishing of information) by the medium. The second explanation, the spiritualist model, argues that the mind (or soul) of the medium communicates with the mind (or soul) of the deceased person through some form of telepathy, obtaining information. From the third perspective, generally defended by investigators of ESP, when an alleged medium is asked to communicate with a deceased person, the medium's answers are given based on clairvoyant access to physical traits of the deceased personality and on telepathic access to the knowledge of the consultant (super-psi hypothesis). The supporters of this explanation, in general, also consider the survival as a plausible hypothesis requiring evidence-based proof ${ }^{23}$. This variety of possible explanations, hard to differentiate one from another, poses significant challenges and complexity for the studies aiming to prove the reality of mediumistic phenomena.

In fact, the last decade has been particularly productive for this field of research and the study of mediumship can help the understanding of the human mind-brain relationship and provide objective data to the scientific community and to the general population. Within this context, the aim of this review is to summarize and discuss the recent results found on studies investigating mediumship. Furthermore, we aim to discuss the psychophysiology underlying mediumship and future perspectives for this study topic.

\section{Methods}

\section{Literature review and selection of studies}

The Literature search strategy was carried out in three phases, as described below.

Phase 1 (primary Literature search): two researchers (MAVBJ and IHSO) independently screened the list of citations (full text were retrieved for further analysis whenever necessary) to exclude studies that did not address the issue at hand. Any disagreement between the researchers were discussed with a third reviewer (GL), and resolved by reaching a consensus.

Articles in English, Portuguese and Spanish dealing with quantitative investigation of mediumship, published within the time range from January $1^{\text {st }}, 2000$ up to June $10^{\text {th }}, 2015$, were selected - hence focusing only on the contemporary scientific aspects of the topic.

Review articles, qualitative studies (either anthropological, theological or ethnographic), studies investigating altered states of consciousness caused by psychoactive substances and letters to the editor were excluded. Regarding the studies testing accuracy of me- diumistic information, works that have not applied rigorous designs aiming to eliminate information leakage (i.e. those not strictly adhering to protocols that minimize as much as possible the probability of the alleged medium having access to information about the deceased personality via other common means or via fishing of information) were also excluded. Regarding psychophysiologic correlates of alleged mediumship, due to extreme paucity of available data, case reports were not excluded. All articles not fulfilling the inclusion criteria and which met the exclusion criteria were omitted from the final analysis.

The following databases were evaluated: Web of Science, PubMed and Lilacs. For the Web of Science database, filters were used to limit the search to fields of Psychiatry, Psychology, Neurosciences/ Neurology, Religion and General Internal Medicine, as this database also indexes citations in arts and humanities, which are beyond the scope of this review.

The keywords used were: "mediumship", "mediumistic" and "after-death communication". Although a few important concepts and theories accrued from anthropological and ethnographic studies about Possession Trance are cited, this is not the focus of this review.

Phase 2 (secondary Literature search): with the aim of identifying studies that could have been missed in the primary search, references lists of initially included articles were screened and the same three keywords were evaluated in Google Scholar. Only the first 100 references from Google Scholar were evaluated. The same inclusion and exclusion criteria were applied in both phase 1 and phase 2 .

Phase 3 (critical review of studies): the included articles were evaluated regarding number of participants, methods applied, comparisons and main findings. The studies were grouped in the following three categories based on their methodology and type of outcomes evaluated: (1) mediumship and psychopathology, (2) testing the accuracy of information provided by mediums and (3) psychophysiological correlates of mediumship. These categories were adopted based on the classification proposed by Jinks (2013) ${ }^{24}$ for quantitative research on mediumship.

Table 1 and figure 1 summarize the search and selection strategy.

The last section of this review consist of future perspectives for the study of alleged mediumship, especially in its psychophysiological aspects, and due to paucity of available empirical data on this field, it was based on authors' opinions and on recent reviews dealing with other dissociative and spiritual experiences.

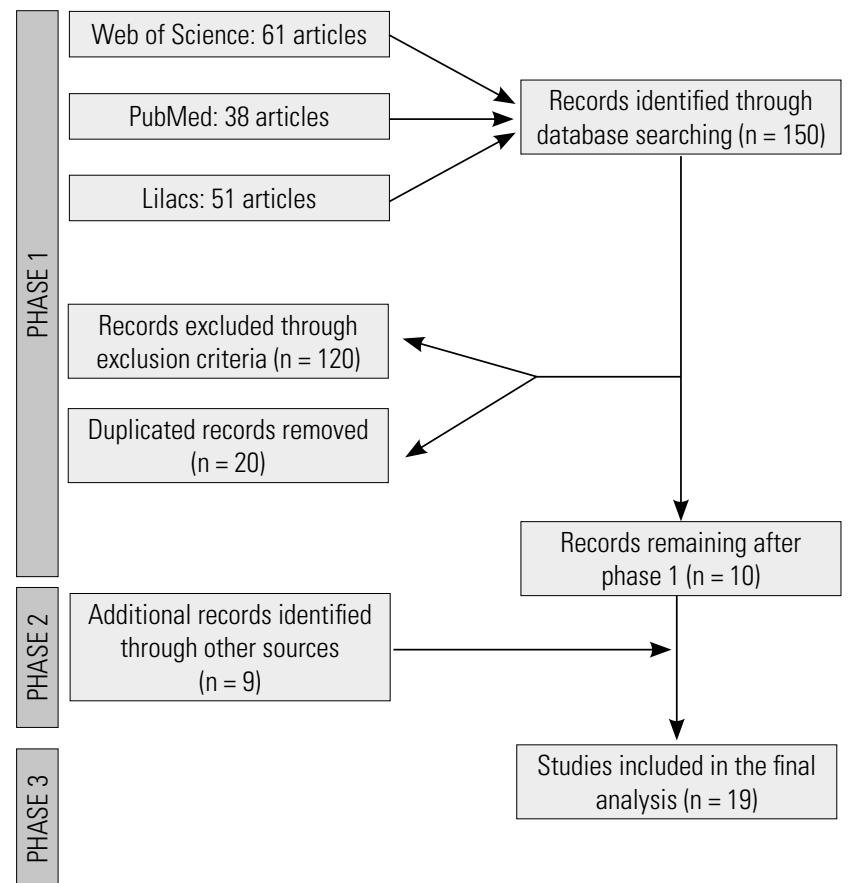

Figure 1. PRISMA (The Preferred Reporting Items for Systematic Reviews and Meta-Analysis) flow diagram. 
Table 1. Selection of studies - phase 1

\begin{tabular}{|c|c|c|c|c|}
\hline Term & $\mathrm{N}^{\circ}$ of articles found & $\mathrm{N}^{\circ}$ of articles excluded & Reasons for exclusion & $\begin{array}{l}\mathrm{N}^{\circ} \text { of articles included } \\
\text { in final analysis }\end{array}$ \\
\hline & \multicolumn{4}{|c|}{ Electronic database: Web of Science } \\
\hline "Mediumship" & 40 & 32 & $\begin{array}{l}9 \text { ethnographic studies } \\
8 \text { literature reviews } \\
8 \text { historical perspective articles } \\
7 \text { other reasons }\end{array}$ & 8 \\
\hline "Mediumistic" & 17 & 16 & $\begin{array}{l}5 \text { historical perspective articles } \\
4 \text { literature reviews } \\
4 \text { ethnographic studies } \\
3 \text { other reasons }\end{array}$ & 1 \\
\hline \multirow[t]{2}{*}{ "After-death communication" } & 4 & 4 & \begin{tabular}{|l|}
2 qualitative studies \\
1 literature review \\
1 ethnographic study \\
\end{tabular} & 0 \\
\hline & \multicolumn{4}{|l|}{ Electronic database: PubMed } \\
\hline "Mediumship" & 21 & 13 & $\begin{array}{l}6 \text { historical perspective articles } \\
2 \text { ethnographic studies } \\
2 \text { literature reviews } \\
3 \text { other reasons }\end{array}$ & 8 \\
\hline "Mediumistic" & 12 & 10 & $\begin{array}{l}2 \text { ethnographic studies } \\
2 \text { historical perspective articles } \\
6 \text { other reasons }\end{array}$ & 2 \\
\hline \multirow[t]{2}{*}{ "After-death communication" } & 5 & 5 & \begin{tabular}{|l|}
3 qualitative studies \\
1 literature review \\
1 letter to editor \\
\end{tabular} & 0 \\
\hline & \multicolumn{4}{|l|}{ Electronic database: Lilacs } \\
\hline "Mediumship" & 30 & 21 & $\begin{array}{l}8 \text { historical perspective articles } \\
6 \text { literature reviews } \\
4 \text { ethnographic studies } \\
3 \text { other reasons } \\
\end{array}$ & 9 \\
\hline "Mediumistic" & 17 & 15 & $\begin{array}{l}5 \text { historical perspective articles } \\
3 \text { literature reviews } \\
2 \text { ethnographic studies } \\
5 \text { other reasons }\end{array}$ & 2 \\
\hline \multirow[t]{3}{*}{ "After-death communication" } & 4 & 4 & \begin{tabular}{|l|}
2 qualitative studies \\
1 literature review \\
1 letter to editor \\
\end{tabular} & 0 \\
\hline & \multicolumn{4}{|l|}{ All Databases } \\
\hline & & 20 & $\begin{array}{l}\text { Duplicated articles among those } \\
\text { included }\end{array}$ & \\
\hline Total & 150 & 140 & & $10^{*}$ \\
\hline
\end{tabular}

* The phase 2 of the search led to the inclusion of 9 additional articles totaling 19 articles for the final analysis.

\section{Results and discussion}

The phase 1 (primary Literature search) of the search led to the retrieval of a total of 150 articles. The application of the exclusion criteria resulted in the exclusion of 140 articles and the inclusion of 10 articles in this phase. As shown in table 1, the most frequent reasons for excluding articles, in descending order, were: historical perspective studies ( 34 articles), literature reviews (25 articles) and ethnographic studies (24 articles).

In phase 2 (secondary Literature search) of the search, screening of references lists and evaluating the keywords in Google Scholar led to the inclusion of 9 additional articles.

In phase 3 (critical review of studies), all 19 studies found were evaluated in terms of number of participants, methods applied, comparisons and main findings.

Tables 2, 3 and 4 briefly describe the 19 included studies. The main results are as follows:

(1) Mediumship and psychopathology (Table 2)

Most studies suggest that mediums have good mental health, are socially well adapted and occupationally active. However, one must notice that all but one study ${ }^{25}$ took place in Brazil, so caution is necessary when trying to extrapolate these conclusions to other countries, since mediums have an established social role in Brazil26, which may not be the case in other societies. It is known that a society's dominant ideas about questions like the dualism, the soul and paranormality influences the way dissociative experiences are viewed and whether they are tolerated or not ${ }^{17}$.

Our findings corroborate with the theory proposed by Selig$\operatorname{man}^{14}$ that affirms that mediumship has a therapeutic role to certain individuals under psychological distress, who find in the religious system a way for a positive transformation of their identities. The scores of mental health and control of the dissociative experiences are clearly different if the individuals are beginning to participate in the religion, as in the studies of Menezes Jr. et al. ${ }^{2}$ and Alminhana et al. ${ }^{27}$, or if they have many years of practice as socially sanctioned mediums, as it was the case in all the other studies, being significantly worse in the former case.

However, the psychosocial stressors theory may not fully explain the Brazilian Spiritist participants, since this group has one of the country's best socioeconomic status and best education level among all the other religious groups ${ }^{28}$. For instance, in the study of MoreiraAlmeida (2004) 29 , the financial situation of Spiritist mediums was not different from mentally healthy control participants, highlighting that other possible explanation for this phenomenon may be considered ${ }^{14}$. 
Table 2. Studies on mediumship and psychopathology

\begin{tabular}{|c|c|c|c|c|}
\hline Study & Participants & Method & Comparisons & Findings \\
\hline $\begin{array}{l}\text { Negro et al. } \\
(2002)^{73}\end{array}$ & $\begin{array}{l}110 \text { experienced Kardecists } \\
\text { mediums (for } 21 \text { years on } \\
\text { average) }\end{array}$ & $\begin{array}{l}\text { Self-report questionnaires } \\
\text { (SROs) evaluating personality } \\
\text { traits (happiness, sociability, } \\
\text { religiosity, temper, mediumship) } \\
\text { and dissociative experiences } \\
\text { (Dissociative Experiences Scale } \\
\text { - DES) }\end{array}$ & $\begin{array}{l}\text { Correlation analysis between } \\
\text { dissociation scores and } \\
\text { sociability and adaptation } \\
\text { scores. } \\
\text { Correlation analysis between } \\
\text { training in mediumship } \\
\text { and control of dissociative } \\
\text { experiences }\end{array}$ & $\begin{array}{l}\text { Sociability and adaptation scores compatible } \\
\text { with normality despite high dissociation } \\
\text { scores. } \\
\text { Majority (94\%) considered to have control } \\
\text { over the mediumistic experience. Positive } \\
\text { correlation between formal training in } \\
\text { mediumship and control of dissociative } \\
\text { experiences }\end{array}$ \\
\hline $\begin{array}{l}\text { Moreira-Almeida } \\
(2004)^{29}\end{array}$ & $\begin{array}{l}115 \text { Kardecist active mediums } \\
\text { (for } 16 \text { years on average) and } \\
34 \text { subjects without previous or } \\
\text { current mental disorder }\end{array}$ & $\begin{array}{l}\text { Semi-structured interviews } \\
\text { and self-report questionnaires } \\
\text { assessing: socio-demographic } \\
\text { data, mental health and } \\
\text { phenomenology of dissociative } \\
\text { experiences }\end{array}$ & $\begin{array}{l}\text { Comparison of prevalence } \\
\text { of hallucinatory experiences } \\
\text { between groups. Correlation } \\
\text { analysis between dissociative } \\
\text { symptoms scores and intensity } \\
\text { of mediumistic activity with } \\
\text { mental health scores and social } \\
\text { adequacy }\end{array}$ & $\begin{array}{l}\text { Higher prevalence of hallucinatory experiences } \\
\text { in mediums, with normal levels of social } \\
\text { adequacy. There was no correlation between } \\
\text { the intensity of mediumistic activity and } \\
\text { mental health scores and social adequacy }\end{array}$ \\
\hline Seligman $(2005)^{14}$ & $\begin{array}{l}\text { Five groups: } \\
-11 \text { female Candomblé } \\
\text { mediums } \\
-10 \text { non-medium initiates, } \\
-20 \text { uninitiated religious } \\
\text { frequenters, } \\
-20 \text { control participants from } \\
\text { outside the religion, matched } \\
\text { for socio-economic status, } \\
-10 \text { control participants from } \\
\text { outside the religion and from } \\
\text { a higher socioeconomic status }\end{array}$ & $\begin{array}{l}\text { - Instrument to screen for } \\
\text { anxiety and depression } \\
\text { (QMPA) } \\
\text { - State Trait Anxiety Inventory } \\
\text { (STAI) } \\
\text { - Dissociative Experiences } \\
\text { Scale (DES) } \\
\text { - Semi-structured interviews }\end{array}$ & $\begin{array}{l}\text { Comparison between mediums } \\
\text { and nonmediums with varying } \\
\text { degrees of proximity to } \\
\text { Candomblé and the mediumship } \\
\text { role }\end{array}$ & $\begin{array}{l}\text { Group from higher socioeconomic status } \\
\text { with significantly lower levels of anxiety } \\
\text { and depression (QMPA). Significantly higher } \\
\text { number of somatic symptoms reported by } \\
\text { mediums. No difference between groups } \\
\text { for STAl scores. DES scores higher in the } 3 \\
\text { religious groups (none above clinical cut-off). } \\
\text { No correlation between mediumship and DES } \\
\text { score }\end{array}$ \\
\hline $\begin{array}{l}\text { Moreira-Almeida } \\
\text { et al. } \\
(2008)^{26}\end{array}$ & $\begin{array}{l}24 \text { Kardecist active mediums, } \\
\text { being } 12 \text { mediums with (+) } \\
\text { scores in the screening for } \\
\text { mental disorders in primary care } \\
\text { [SR0 +] and } 12 \text { mediums with (-) } \\
\text { scores [SRO -] } \\
166 \text { patients with Dissociative } \\
\text { Identity Disorder - DID (data } \\
\text { from this group was extracted } \\
\text { from literature) }\end{array}$ & $\begin{array}{l}\text { Self-report questionnaire } \\
\text { assessing social adequacy, } \\
\text { psychotic symptoms and } \\
\text { structured interviews with } \\
\text { mediums to evaluate diagnostic } \\
\text { criteria for DID }\end{array}$ & $\begin{array}{l}\text { Comparison between subgroups } \\
\text { of mediums. Comparison } \\
\text { between mediums and patients } \\
\text { with DID }\end{array}$ & $\begin{array}{l}\text { From the mediums, no one met criteria for } \\
\text { DID. The only difference observed among the } \\
\text { subgroups of mediums was social adaptation } \\
\text { [slightly worse in SRQ (+)]. No difference } \\
\text { between the group of mediums and DID group } \\
\text { for psychotic symptoms, but better mental } \\
\text { health and social adjustment in mediums }\end{array}$ \\
\hline $\begin{array}{l}\text { Roxburgh \& Roe } \\
(2011)^{25}\end{array}$ & $\begin{array}{l}80 \text { British spiritualist mediums } \\
\text { and } 79 \text { control subjects (non- } \\
\text { mediums, attended the same } \\
\text { religion, without any diagnosed } \\
\text { mental disorder) }\end{array}$ & $\begin{array}{l}\text { Self-report questionnaires } \\
\text { assessing personality traits and } \\
\text { mental health indicators }\end{array}$ & $\begin{array}{l}\text { Comparison between mediums } \\
\text { and control group (healthy } \\
\text { individuals from the same } \\
\text { socio-cultural context) }\end{array}$ & $\begin{array}{l}\text { Mediums scored significantly higher in well- } \\
\text { being and lower in psychological stress. There } \\
\text { were no significant differences among groups } \\
\text { regarding dissociation or personality traits that } \\
\text { could indicate psychopathology or proneness } \\
\text { to fantazise }\end{array}$ \\
\hline $\begin{array}{l}\text { Menezes Jr. et } \\
\text { al. }(2012)^{2}\end{array}$ & $\begin{array}{l}115 \text { individuals seeking help in } \\
\text { spiritual centers due to their so- } \\
\text { called mediumistic experiences }\end{array}$ & $\begin{array}{l}\text { Semi-structured interview with } \\
\text { a psychologist to evaluate } \\
\text { socio-demographic data, mental } \\
\text { health history and dissociative } \\
\text { experiences }\end{array}$ & $\begin{array}{l}\text { Qualitative exploration to } \\
\text { assess the presence or not } \\
\text { of nine criteria considered } \\
\text { suggestive of non-pathological } \\
\text { anomalous experiences (AEs) }\end{array}$ & $\begin{array}{l}\text { The most frequent AEs were visual (63\%) and } \\
\text { hearing ( } 54 \% \text { ) hallucinations and "perception } \\
\text { of spirit" ( } 53 \%) \\
\text { For most of mediums, AE did not bring socio- } \\
\text { occupational losses, were brief, episodic } \\
\text { and benefic; but } 59.2 \% \text { related them with } \\
\text { emotional distress and } 54.8 \% \text { did not present } \\
\text { control over experiences }\end{array}$ \\
\hline $\begin{array}{l}\text { Alminhana et al. } \\
(2013)^{27}\end{array}$ & $\begin{array}{l}115 \text { individuals seeking help in } \\
\text { spiritual centers due to their so- } \\
\text { called mediumistic experiences }\end{array}$ & $\begin{array}{l}\text { Self-report questionnaires to } \\
\text { assess personality traits, quality } \\
\text { of life and religiosity }\end{array}$ & $\begin{array}{l}\text { Comparison between } \\
\text { experimental group, general } \\
\text { population and individuals } \\
\text { with mental disorders (data of } \\
\text { control groups extracted from } \\
\text { literature) }\end{array}$ & $\begin{array}{l}\text { Individuals with AE presented intermediate } \\
\text { scores on personality traits, religiosity and } \\
\text { quality of life when compared with general } \\
\text { population and individuals with mental } \\
\text { disorders. Authors hypothesized that mediums } \\
\text { may be a population at higher risk for mental } \\
\text { disorders }\end{array}$ \\
\hline
\end{tabular}


(2) Accuracy of information provided by mediums (Table 3)

Quantitative research on alleged mediums has been done for more than a hundred years, and meanwhile the designs of studies have been progressively improved as to eliminate information leakage and telepathy as explanations for the reception of accurate information by mediums ${ }^{23}$. Research protocols reproduce the habitual situation of a friend or relative (the named "sitters") of a deceased person consulting a claimed medium looking for postmortem information about this person, but they apply a "triple blind" design ${ }^{30}$. That is, mediums are blind to the identities of the consultant ("sitter") and of his/her related-deceased person; the researcher interacting with the mediums (acting as a proxy for the consultant) also remains blind to the identities of the consultants and his/her related-deceased person; and consultants who score the accuracy of the "readings" remain blind about the information source (reading really intended for him/her $v s$ decoy reading) ${ }^{18}$.

In the present review, only studies considered to have sufficient control against information leakage (i.e. which strictly adhered to triple-blind protocols) were included. Hence the works of Roy \& Robertson ${ }^{31}$ and Schwartz et al. ${ }^{32}$, although consist of important contributions as exploratory methods, were excluded (they applied methods where mediums had direct contact and talked to the consultants, among other shortcomings). Data from experiment 2 of the study of Kelly \& Arcangel ${ }^{33}$ was also excluded from this review because of lack of strict adherence to triple-blind protocol (mediums received pictures from the deceased individuals, many of the sitters were colleagues or friends of one of the investigators, and this investigator knew some of the deceased individuals). Altogether the results of the well-controlled studies included in this review show: (a) in two studies ${ }^{30,34}$ (totaling 28 mediums and 102 readings) the sitters' accuracy ratings of specific information from target readings were statistically higher than for decoy readings; and (b) in three ${ }^{33,35,36}$ studies (totaling 10 mediums and 44 readings) there was no statistical difference in the fit scores assigned by sitters for the target or decoy readings.

Interestingly, the "triple-blind" design was used in all these studies, but there were slight methodological differences between them that can have influenced the outcomes. For example, in the studies with positive results, the sitters were asked to decide which was the fittest between only two readings, while in "negative studies" the sitters needed to decide among three to seven readings. Moreover, "positive" but not "negative" studies have used a pairing procedure of the deceased persons to optimize differences (in categories like age at passing, hobbies, physical description, cause of death). Hence, it seems that, for methodological reasons, choosing the target reading was less difficult for sitters of the "positive" than for "negative" studies.

Different from the others, the study of Rocha et al. ${ }^{37}$ did not use a controlled design, choosing a retrospective approach. Authors screened published and unpublished letters that were psychographed (allegedly written under the influence of a spirit) by a Brazilian medium, Chico Xavier, who died in 2002. Then, a set of 13 letters was selected because these letters contained much specific and objective information about a deceased person, and living relatives and friends of this person agreed to participate in interviews with the investigators to verify the fit and accuracy of the mediumistic information conveyed. Among 71 items of specific information extracted from the letters, a high percentage $(97,2 \%)$ was scored as having a "clear and precise fit". As authors acknowledge, one significant limitation of this type of study is that the scoring may have been subject to memory bias, as letters were written more than forty years before. However, three "drop-in" communications ("situations where allegedly a deceased personality communicates via the medium without the request of relatives or friends" ${ }^{37}$ ) were identified in the letters. Pieces of specific information from these communications were objectively verified, and they proved to be true.

(3) Psychophysiological correlates of mediumship (Table 4)

The most common findings concerning psychophysiological correlates of mediumship were: increased noradrenalin levels during possession trance in a controlled study ${ }^{38}$, increased muscle tone in a case report ${ }^{39}$, increased heart rate ${ }^{38,39}$ and increased spectral power in various EEG frequency bands during mediumistic communication and possession trance ${ }^{40,41}$. None of the studies included in this review has demonstrated an ictal pattern on EEG during the experience. These results could point to a state of mental and physical arousal during the phenomena ${ }^{42,43}$.

On the other hand, the only study using functional neuroimaging, in this case a Single Positron Emission Tomography (SPECT), showed a reduction of cerebral blood flow (CBF) in left culmen, left hippocampus, left inferior occipital gyrus, left anterior cingulated cortex, right superior temporal gyrus and right pre-central gyrus (brain areas associated with memory, language and writing planning) during mediumistic communication (psychography) as compared to a control task. There was also a surprising negative correlation between the $\mathrm{CBF}$ in these areas and the linguistic complexity of the written text produced during psychography ${ }^{15}$. Taken together with the case series report of a slowing of background EEG activity in some mediums during psychophony (allegedly speaking under the influence of a spirit) and psychography ${ }^{44}$ these data could suggest the activation of fewer neuronal populations during the dissociative experience.

Considering the dominant current psychobiological explanation for the possession trance and mediumship, there is a number of authors, which propose the role of self-hypnosis ${ }^{14,17}$. Hypnosis is seen as a state of focused attention and concentration, inner absorption and a relative suspension of external awareness. There is evidence for a correlation between hypnotizability and number of dissociative symptoms and that patients with dissociative disorders have higher rate of hypnotizability. Although differences occur according to the phase of hypnotic procedure (relaxation - induction - suggestion - waking up) and to which actions are suggested to the individual, many studies show increased theta power during hypnosis, indicating an intensification of attention processes. Regarding functional neuroimaging, the most characteristic finding of the hypnotic state is the hypoactivity of the "extrinsic brain network", which encompasses lateral fronto-parietal regions and which has been linked to cognitive processes of external sensory input. The reduced activity of this network can reflect a blocking of the sensorial systems to receive stimulus. A structural Magnetic Ressonance study has shown neuro-anatomical differences between high and low hypnotizable individuals: larger (32\%) rostrum of the corpus callosum in highs than in lows. This area is involved in the information transfer between pre-frontal cortices and in attention allocation. The authors suggest that high hypnotizable subjects would have more efficient frontal attentional systems, with greater ability to monitor performance and to inhibit undesirable stimulus for conscious awareness ${ }^{45}$.

Although it is not possible to say that spontaneous dissociative symptoms, like mediumship, share strictly the same neurophysiological processes of hypnosis, evidence suggest that many parallels can be drawn between them ${ }^{45}$. There are already some reports of research groups using hypnosis on healthy individuals to "model" dissociative symptoms (e.g. "automatic writing") and more easily study them in the neurophysiology and neuroimaging lab ${ }^{46,47}$. This strategy might bring valuable complementary data for the understanding of the neurobiology of alleged mediumship.

\section{Future perspectives}

Mediumship is a controversial research topic with ongoing experiments. Regarding its relation to psychopathology, in practical terms, it is important to avoid the risk of a "category fallacy". In other words, here both risks exist and should be avoided: pathologizing normal religious experiences and considering potentially dangerous clinical conditions as a common religious/spiritual experience. Thus, if such cases of mediumship and possession come to medical attention, besides a comprehensive assessment of the sociocultural implications and of the possible secondary gains for the individual, a standard psychiatric evaluation should not be neglected. In this evaluation, not only the patient but also family and community 
members should be interviewed, so that the extent of impairment of daily life by the dissociative experiences can be inferred. Possible psychiatric comorbidities should also be sought. The most commonly used type of therapy for possession disorders is psychotherapy, and some scholars advise it should focus on the stressing factors that can initiate the dissociative phenomena ${ }^{48,49}$.

Concerning studies on the accuracy of information provided by mediums, their design must reach a balance between control against information leakage and the provision of a research environment that optimizes the phenomenon for both the medium and for the alleged communicating deceased person $36,50-52$. Apparently, among the reviewed studies, the protocol proposed by Beischel is the most successful in meeting these conditions, and it requires replication by other research groups to broaden the database and to eventually demonstrate or not the scientific evidence of mediumship. Notwithstanding, some investigators affirm that even accurate results of mediumship studies do not prove the postmortem survival hypothesis and that the best explanation would still be some form of telepathy between the medium and other "living agent psi" 53 .

Studies evaluating physiological correlations during mediumistic communications are still very incipient. Here, as for other types of psychophysiologic studies, the employment of a process-based approach is recommended ${ }^{54}$. Before initiating any data collection, a detailed definition of the phenomenon, based on systematic observation, is necessary. This should include a definition, as precise as possible, of when the mediumistic communication begins and when it ends. Proper initial definitions about the process under investigation are necessary if one aims to obtain valid physiological research data about it 55 .

Table 3. Studies on the accuracy of mediumistic information

\begin{tabular}{|c|c|c|c|c|}
\hline Study & Participants & Method & Comparison & Findings \\
\hline $\begin{array}{l}\text { O'Keefe \& } \\
\text { Wiseman } \\
(2005)^{35}\end{array}$ & $\begin{array}{l}5 \text { professional mediums and } 5 \\
\text { consultants ("sitters") }\end{array}$ & $\begin{array}{l}\text { Triple-blind study, properly } \\
\text { executed. Five "readings" were } \\
\text { itemized, grouped and sent to } \\
\text { consultants for "blind" scoring } \\
\text { of items for accuracy and } \\
\text { applicability }\end{array}$ & $\begin{array}{l}\text { Comparison between scores of } \\
\text { "readings" really intended for } \\
\text { the consulent with the scores } \\
\text { of readings made for other } \\
\text { consultants }\end{array}$ & $\begin{array}{l}\text { There was no significant difference between } \\
\text { scores. In only one occasion the consultant } \\
\text { assigned higher scores to the "reading" that } \\
\text { was directed to him. }\end{array}$ \\
\hline $\begin{array}{l}\text { Beischel \& } \\
\text { Schwartz } \\
\text { (2007) })^{30}\end{array}$ & \begin{tabular}{|l|}
8 mediums (who had previously \\
demonstrated ability to provide \\
mediumistic information with \\
accuracy, according to the \\
authors) and 8 consultants (highly \\
motivated to receive information \\
from deceased relatives) \\
\end{tabular} & $\begin{array}{l}\text { Triple-blind study, properly } \\
\text { executed. Each "blind" } \\
\text { consultant received two } \\
\text { "readings" to score accuracy } \\
\text { and choose which of them } \\
\text { better applied to his/her } \\
\text { deceased family member }\end{array}$ & $\begin{array}{l}\text { Comparison between "reading" } \\
\text { scores that supposedly came } \\
\text { from the deceased family } \\
\text { member and "reading" scores } \\
\text { that were directed to other } \\
\text { consultants }\end{array}$ & $\begin{array}{l}\text { The consultants chose the correct "reading" } \\
\text { (directed to them) in } 81 \% \text { of cases }(13 / 16) \text {. } \\
\text { The "reading" scores from messages directed } \\
\text { to them were significantly higher than control } \\
\text { "reading" scores }\end{array}$ \\
\hline $\begin{array}{l}\text { Jensen \& } \\
\text { Cardeña } \\
(2009)^{36}\end{array}$ & $\begin{array}{l}1 \text { professional experienced } \\
\text { medium and } 7 \text { consultants } \\
\text { ("sitters") }\end{array}$ & $\begin{array}{l}\text { Triple-blind study, properly } \\
\text { executed. Seven "readings" } \\
\text { were itemized, grouped and } \\
\text { sent to consultants for "blind" } \\
\text { scoring of items for accuracy } \\
\text { and applicability }\end{array}$ & \begin{tabular}{|l|} 
Comparison between scores of \\
7 "readings" (one reading really \\
intended for the consultant and \\
6 other decoy readings")
\end{tabular} & $\begin{array}{l}\text { Scores assigned by the consultants for neither } \\
\text { global nor specific information from "target } \\
\text { readings" were significantly better than } \\
\text { expected by chance. No sitter chose his target } \\
\text { reading as the most applicable. Measures } \\
\text { of paranormal belief of sitters positively } \\
\text { correlated with rating of reading }\end{array}$ \\
\hline $\begin{array}{l}\text { Kelly \& Arcangel } \\
(2011)^{33}\end{array}$ & $\begin{array}{l}\text { Experiment } 1 \text { : } \\
4 \text { mediums and } 12 \text { consultants } \\
\text { Experiment 2: } \\
9 \text { mediums and } 40 \text { consultants }\end{array}$ & $\begin{array}{l}\text { Triple-blind study adequately } \\
\text { performed only in experiment } 1\end{array}$ & $\begin{array}{l}\text { Comparison between "reading" } \\
\text { scores that supposedly came } \\
\text { from the deceased family } \\
\text { member and "reading" scores } \\
\text { that were directed to other } \\
\text { consultants } \\
\text { Note: consultants chose } \\
\text { one reading among three in } \\
\text { experiment } 1 \text { and chose one } \\
\text { reading among } 6 \text { in experiment } 2\end{array}$ & $\begin{array}{l}\text { Experiment 1: only } 2 \text { of } 12 \text { consultants were } \\
\text { able to identify the "reading" directed to them } \\
\text { ( } 3 \text { hits would be expected to occur by chance) } \\
\text { Experiment 2: } 14 \text { of } 38 \text { consultants chose } \\
\text { the correct "reading" and } 30 \text { consultants } \\
\text { positioned the "reading" directed to them } \\
\text { among the three first places s in the accuracy } \\
\text { rank }\end{array}$ \\
\hline $\begin{array}{l}\text { Rocha et al. } \\
(2014)^{37}\end{array}$ & $\begin{array}{l}5 \text { relatives and friends of a } \\
\text { deceased personality (JP), who } \\
\text { is the alleged } \\
\text { spiritual author of } 13 \\
\text { psychographed letters (by the } \\
\text { spiritist medium Chico Xavier) }\end{array}$ & $\begin{array}{l}\text { Verifiable items were extracted } \\
\text { from the letters. Interviews with } \\
\text { participants to assess items' } \\
\text { fit and accuracy and probability } \\
\text { of information leakage. Based } \\
\text { on the interviews, three } \\
\text { researchers scored each item } \\
\end{array}$ & $\begin{array}{l}\text { Comparison of types of } \\
\text { verifiable information. } \\
\text { Comparison of scores of fit } \\
\text { and of information leakage } \\
\text { probability between the items } \\
\text { from the first letter and the } \\
\text { subsequent letters } \\
\end{array}$ & $\begin{array}{l}\text { The percentage of "clear and precise fit" } \\
\text { among the } 71 \text { verified items was } 97.2 \% \text {. } \\
\text { Considering the first letter (written } 40 \\
\text { days after JP's death), } 100 \% \text { of the items } \\
\text { were scored as "very unlikely leakage". For } \\
\text { subsequent letters, } 63 \% \text { of the items were } \\
\text { scored as "unlikely leakage" }\end{array}$ \\
\hline $\begin{array}{l}\text { Beischel et al. } \\
(2015)^{34}\end{array}$ & $\begin{array}{l} \\
\text { Experiment 2: } \\
20 \text { mediums and } 40 \text { consultants } \\
\text { (total of } 20 \text { mediums, } 18 \text { of } \\
\text { them female, with same } \\
\text { characteristics as from study of } \\
\text { Beischel } \& \text { Schwartz, 2007) } \\
\text { (total of } 86 \text { readings) }\end{array}$ & $\begin{array}{l}\text { Experiment } 1 \& \text { 2: Triple-blind } \\
\text { study, properly executed. Each } \\
\text { "blind" consultant received } \\
\text { two "readings" to score } \\
\text { accuracy and choose which of } \\
\text { them better applied to his/her } \\
\text { deceased family member } \\
\text { Experiment 2: } 12 \text { of the } \\
\text { readings took place during } \\
\text { an examination of EEG of } 6 \\
\text { mediums }\end{array}$ & $\begin{array}{l}\text { Comparison between "reading" } \\
\text { scores that supposedly came } \\
\text { from the deceased family } \\
\text { member and "reading" scores } \\
\text { that were directed to other } \\
\text { consultants }\end{array}$ & $\begin{array}{l}\text { The scores assigned by the consultants for } \\
\text { both global and specific information from } \\
\text { "target readings" were significantly higher } \\
\text { than for "decoy readings". Significantly higher } \\
\text { percentage accuracy of "target reading" items }\end{array}$ \\
\hline
\end{tabular}


Table 4. Studies involving psychophysiological correlates of mediumship

\begin{tabular}{|c|c|c|c|c|}
\hline Study & Participants & Method & Comparison & Findings \\
\hline $\begin{array}{l}\text { Kawai et al. } \\
(2001)^{38}\end{array}$ & $\begin{array}{l}15 \text { subjects presenting an } \\
\text { alleged possession trance while } \\
\text { participating in a religious ritual } \\
\text { and } 9 \text { subjects participating in } \\
\text { the same religious ritual but not } \\
\text { presenting a possession trance }\end{array}$ & $\begin{array}{l}\text { Analysis of norepinephrine, } \\
\text { dopamine and beta-endorphin } \\
\text { levels in blood samples. } \\
\text { Assessment of heart rate and } \\
\text { blood pressure }\end{array}$ & $\begin{array}{l}\text { Comparison of plasma levels of } \\
\text { the analytes and of its variation } \\
(\Delta) \text { at baseline and immediately } \\
\text { after the possession trance. } \\
\text { Comparison of the trance and } \\
\text { control groups }\end{array}$ & $\begin{array}{l}\text { The increase in plasma levels of } \\
\text { norepinephrine, dopamine and beta-endorphin } \\
\text { was significantly higher in the group } \\
\text { presenting a possession trance. There was } \\
\text { no significant difference among the groups } \\
\text { regarding blood pressure and heart rate }\end{array}$ \\
\hline $\begin{array}{l}\text { Oohashi et al. } \\
(2002)^{40}\end{array}$ & $\begin{array}{l}\text { One subject during an alleged } \\
\text { possession trance while } \\
\text { participating in a religious ritual } \\
\text { and two subjects participating } \\
\text { in the same religious ritual but } \\
\text { not presenting a possession } \\
\text { trance }\end{array}$ & Electroencephalography (EEG) & $\begin{array}{l}\text { Spectral power analysis for } \\
\text { each EEG frequency band } \\
\text { comparing baseline vs trance } \\
\text { vs recovery in the subject who } \\
\text { went into a trance compared } \\
\text { with the other two }\end{array}$ & $\begin{array}{l}\text { An ictal EEG pattern was not observed. In } \\
\text { the individual who went into a trance, it was } \\
\text { observed an intense and significant increase of } \\
\text { theta and alpha power during the trance state, } \\
\text { when compared with the pre-trance. These } \\
\text { changes persisted in the post-trance period. In } \\
\text { the } 2 \text { control subjects, no significant changes } \\
\text { in spectral power were observed among the } \\
\text { periods }\end{array}$ \\
\hline $\begin{array}{l}\text { Krippner et al. } \\
(2008)^{39} \\
\\
\text { Data colleted in } \\
1999\end{array}$ & $\begin{array}{l}2 \text { mediums (1 spiritist } \\
\text { presenting psychography and } \\
1 \text { from Camdomblé presenting } \\
\text { psychophony) and } 1 \text { control } \\
\text { (no mediumship, same socio- } \\
\text { cultural environment) }\end{array}$ & $\begin{array}{l}\text { Assessment of heart rate, } \\
\text { muscle tone and skin } \\
\text { conductance }\end{array}$ & $\begin{array}{l}\text { Comparison of the percent time } \\
\text { in which each EEG frequency } \\
\text { band was observed during: } \\
\text { baseline vs mediumistic } \\
\text { communication (MC) vs recovery } \\
\end{array}$ & $\begin{array}{l}\text { Spiritist medium: increase in the percentage } \\
\text { of alpha and beta waves during } \mathrm{MC} \text { when } \\
\text { compared with baseline. This pattern persisted } \\
\text { during recovery } \\
\text { Camdomblé medium: increase in the } \\
\text { percentage of theta waves during MC when } \\
\text { compared with baseline } \\
\text { Control subject: increase in the percentage of } \\
\text { alpha waves during control task } \\
\text { In mediums, there was an increase in muscle } \\
\text { tone and slight increase in heart rate during } \\
\text { MC when compared with baseline. In recovery } \\
\text { phase, there was a decrease in muscle tone } \\
\text { and heart rate. There was a reduction of the } \\
\text { mean skin conductance during the MC in one } \\
\text { medium and an increase in the other medium. } \\
\text { In the control subject there was no significant } \\
\text { change in any of these parameters at the } \\
\text { different periods }\end{array}$ \\
\hline $\begin{array}{l}\text { Hageman } \\
\text { et al. } \\
(2010)^{44}\end{array}$ & $\begin{array}{l}9 \text { mediums (6 presenting } \\
\text { psychophony and } 3 \text { presenting } \\
\text { psychography) }\end{array}$ & $\begin{array}{l}\text { Electroencephalography (EEG) } \\
\text { Note: insufficient description of } \\
\text { methodology }\end{array}$ & $\begin{array}{l}\text { Analysis of EEG record looking } \\
\text { for the presence of epileptic } \\
\text { discharge during baseline vs } \\
\text { mediumistic communication } \\
\text { (MC) vs recovery }\end{array}$ & $\begin{array}{l}\text { Ictal EEG pattern was not observed. } \\
\text { A slowing of background activity on the EEG } \\
\text { during MC was observed in } 6 \text { participants }\end{array}$ \\
\hline $\begin{array}{l}\text { Peres et al. } \\
(2012)^{15}\end{array}$ & $\begin{array}{l}10 \text { spiritist mediums (allocated } \\
\text { in } 2 \text { groups: } 5 \text { more experienced } \\
\text { and } 5 \text { less experienced) }\end{array}$ & $\begin{array}{l}\text { Functional neuroimaging } \\
\text { (SPECT). Evaluation of linguistic } \\
\text { complexity of texts written } \\
\text { under controlled conditions }\end{array}$ & $\begin{array}{l}\text { Comparison of regional } \\
\text { cerebral blood flow (CBF) } \\
\text { during automatic writing } \\
\text { (psychography) and during } \\
\text { control task (writing a } \\
\text { text in the usual state of } \\
\text { consciousness). Correlation } \\
\text { analysis between neuroimaging } \\
\text { findings and linguistic } \\
\text { complexity of the texts }\end{array}$ & $\begin{array}{l}\text { Hypoactivation of brain regions responsible } \\
\text { for cognitive processing and writing planning } \\
\text { during psychography } \\
\text { Inverse correlation trend: increasing levels of } \\
\text { linguistic complexity of the texts produced during } \\
\text { psychography associated with gradual reduction } \\
\text { in CBF in brain regions responsible for cognitive } \\
\text { processing and writing planning }\end{array}$ \\
\hline $\begin{array}{l}\text { Delorme et al. } \\
(2013)^{41}\end{array}$ & 6 professional mental mediums & $\begin{array}{l}\text { Experiment 1: triple-blind } \\
\text { design to investigate } \\
\text { accuracy of the information } \\
\text { provided by mediums + } \\
\text { Electroencephalography (EEG) } \\
\\
\text { Experiment 2: analysis of EEG } \\
\text { records of mediums while } \\
\text { performing } 4 \text { different mental } \\
\text { tasks: perception, memory, } \\
\text { imagination and mediumistic } \\
\text { communication (MC) }\end{array}$ & $\begin{array}{l}\text { Experiment 1: correlational } \\
\text { analysis between the accuracy } \\
\text { of mediumistic information } \\
\text { provided and the EEG spectral } \\
\text { power on each frequency band } \\
\text { during MC } \\
\text { Experiment 2: Comparison of } \\
\text { EEG spectral power on each } \\
\text { frequency band during the } 4 \\
\text { different mental tasks }\end{array}$ & $\begin{array}{l}\text { Experiment 1: significant correlation was } \\
\text { observed in } 2 \text { mediums (in one medium } \\
\text { theta power was negatively correlated with } \\
\text { accuracy and in the other alpha power was } \\
\text { positively correlated with accuracy) } \\
\text { Experiment 2: The most significant difference } \\
\text { occurred between mediumistic communication } \\
\text { and the mental task of perception } \\
\text { Gamma and beta were the frequency bands in } \\
\text { which there were more electrodes revealing } \\
\text { significant differences during the diverse } \\
\text { mental tasks }\end{array}$ \\
\hline
\end{tabular}


Moreover, because spiritual and religious experiences are complex and multidimensional, and because mediums usually describe them in terms of changes in perception, cognition and affect ${ }^{52}$, the measurement of the subjective elements of the phenomena is highly advisable. Posteriorly, a possible correlation among these psychological, affective and cognitive elements with specific brain regions and brain functions can be explored ${ }^{56,57}$. Some examples of instruments that can be used for this purpose are: the Phenomenology of Consciousness Inventory (PCI) ${ }^{58}$, the Assessment Schedule for Altered States of Consciousness (ASASC) ${ }^{59}$ and Hartmann's Boundary Questionnaire ${ }^{60}$, among many others. These questionnaires quantify different phenomenological elements of consciousness and can be useful for helping to distinguish qualitatively different $\mathrm{ASC}^{57}$. Likewise, considering that mediumistic phenomena usually involve dissociative experiences, it is also advisable to conduct a baseline assessment of the personality trait absorption. For this purpose, questionnaires such as the Tellegen Absorption Scale ${ }^{61}$ or the Harvard Group Scale of Hypnotic Susceptibility ${ }^{62}$ could be used. Evidence suggests that individual differences in these characteristics are associated with significant differences in neurological findings ${ }^{63,64}$.

Concerning the possibility of studying mediumship through functional neuroimaging technique, one important aspect is the selection of the control task. Usually the participant acts as his/her own control, being asked to perform two similar tasks, one with and another without spiritual (mediumistic in this case) connotation. This allows the control task to be comparable to mediumistic practice with respect to a range of elements (open or closed eyes, talking or not talking, listening or not listening) and potentially optimizes de identification of characteristic neurophysiological correlates of the mediumistic experience ${ }^{56}$. The decision of which specific method to use depends on availability and financial possibilities ${ }^{52}$ but SPECT (Single-Photon Emission Computed Tomography) and PET (Positron Emission Tomography) techniques are usually preferred because images can be captured after the completion of the event under investigation (not simultaneously as it is necessary for functional Magnetic Resonance Imaging [MRI]). In addition, the noise during MRI may disturb mediums, interfering with the phenomenon ${ }^{56}$.

The electroencephalography (EEG) can also offer important information about the degree of brain activation during the mediumistic practice, particularly of cortical regions. Unlike neuroimaging techniques, which provide excellent spatial location of cerebral functioning but less precise timing information, the EEG provides greater time precision (accuracy of milliseconds, in real time) with much lesser spatial accuracy ${ }^{65}$. However, because EEG recording requires stillness to avoid muscle artifacts, and as mediumship usually involves talking and moving, there might be some technical difficulties.

The objective measurement of physiological parameters that may vary according to the emotions experienced (e.g. heart rate variability - HRV) ${ }^{66,67}$ could also bring relevant contributions to this research field. These parameters can be correlated with subjective self-reports and with neuroimaging findings, bringing to sight a more global physiological picture of the mediumistic phenomenon ${ }^{56}$. Measurements related to the immune and endocrine systems may also contribute to broaden this understanding 68,69 .

Finally, it should be taken into account that different mediumistic modalities may require different study designs. Psychography and psychopictography (allegedly painting under the influence of a spirit) may adapt more easily to an experimental protocol employing functional neuroimaging. In regard of psychophony, although it may represent a larger universe of potential research participants (great prevalence of "spirit release therapy" sessions employing psychophonic mediums in countries such as Brazil ${ }^{70,71}$ and Puerto Rico ${ }^{72}$ ), it offers obstacles to neuroimaging studies as it usually requires team work. In these cases, protocols involving EEG and ECG may be preferred as they allow researchers to record the event "in loco" using portable equipment.

\section{Limitations}

The present study has some limitations, which should be highlighted. First, the searches were limited to English, Spanish and Portuguese; therefore potentially relevant articles published in other languages were not included. Second, although the terms searched are the most frequently used ones, and although three databases were used, potentially relevant articles not indexed in these databases or described with other terms may have been missed.

\section{Conclusions}

The evidence analyzed in this review suggests: (1) mediumship seems to be associated with good mental health, mainly when individuals have many years of work as socially sanctioned mediums (2) there was heterogeneous evidence regarding the accuracy of information provided by alleged mediums, what may be due to different study methodologies, and (3) there is a paucity of studies investigating the physiologic correlates of mediumship. These results emphasize the need for more studies in this field to further elucidate mediumistic experiences, what could broaden the understanding of the mindbrain relationship.

\section{Conflicts of interest}

None of the authors have any conflicts of interest related to writing this review.

\section{References}

1. Rock AJ. Introduction: the medium and the message. In: Rock AJ. The survival hypothesis: essays on mediumship. 1st ed. Jefferson, North Carolina: McFarland \& Company Inc.; 2013. p. 19.

2. Menezes Jr. A, Alminhana L, Moreira-Almeida A. Perfil sociodemográfico e de experiências anômalas em indivíduos com vivências psicóticas e dissociativas em grupos religiosos. Rev Psiquiatr Clin. 2012;39(6):203-7.

3. Plakun EM. Psychiatry in Tibetan Buddhism: madness and its cure seen through the lens of religious and national history. J Am Acad Psychoanal Dyn Psychiatry. 2008;36(3):415-30.

4. Sech Junior A, de Freitas Araujo S, Moreira-Almeida A. William James and psychical research: towards a radical science of mind. Hist Psychiatry. 2013;24(1):62-78.

5. Crabtree A. "Automatism" and the emergence of dynamic psychiatry. J Hist Behav Sci. 2003;39(1):51-70.

6. Stein M. Introdução. In: Stein M. Jung: o mapa da alma - uma introdução. $9^{a}$ ed. São Paulo: Cultrix; 2012. p. 13.

7. Kidd IJ. Was Sir William Crookes epistemically virtuous? Stud Hist Philos Biol Biomed Sci. 2014;48 Pt A:67-74.

8. Alvarado CS, Machado FM, Zangari W, Zingrone NL. Perspectivas históricas da influência da mediunidade na construção de ideias psicológicas e psiquiátricas. Rev Psiquitr Clin. 2007;34(1):42-53.

9. Hunter J, Luke D, editors. Talking with the spirits: ethnographies from between the worlds. Brisbane, Australia: Daily Grail Publishing; 2014.

10. Bourguignon E, editor. Religion, altered states of consciousness, and social change. Columbus (OH): Ohio State University Press; 1973.

11. Greeley AM, Hout M. Americans' increasing belief in life after death religious competition and acculturation. American Sociological Review. 1999;64(6):813-35.

12. Flannelly KJ, Ellison CG, Galek K, Koenig HG. Beliefs about life-afterdeath, psychiatric symptomology and cognitive theories of psychopathology. J Psychology and Theology. 2008;36(2):94-103.

13. Wilson K. A skeptic's view of mediumship. In: Rock AJ. The survival hypothesis: essays on mediumship. 1st ed. Jefferson, North Carolina: McFarland \& Company Inc.; 2013. p. 189.

14. Seligman R. Embodied experience : reconsidering the pathways to mediumship and mental health. Ethos. 2005;33(1):71-99.

15. Peres JF, Moreira-Almeida A, Caixeta L, Leao F \& Newberg A. Neuroimaging during trance state: a contribution to the study of dissociation. PLoS One. 2012;7(11).

16. Krippner S. Cross-cultural treatment perspectives on dissociative disorders. In: Lynn SJ, Rhue JW, editors. Dissociation: Clinical and theoretical perspectives. New York: Guilford; 1994. p. 338-61. 
17. Somer E. Culture-bound dissociation: a comparative analysis. Psychiatr Clin North Am. 2006;29(1):213-26.

18. Moreira-Almeida, A. Research on mediumship and the mind-brain relationship In: Moreira-Almeida A, Santos FS. Exploring frontiers of the mind-brain relationship. 1st ed. New York: Springer; 2012. p. 199.

19. Beauregard M, Schwartz GE, Miller L, Dossey L, Moreira-Almeida A, Schlitz M, et al. Manifesto for a post-materialist science. Explore (NY). 2014;10(5):272-4.

20. Chalmers D. The conscious mind: in search of a fundamental theory. New York: Oxford University Press Inc.; 1996.

21. Searle JR. Why I am not a property dualist. Journal of Consciousness Studies. 2002;9(12):57-64.

22. Brandão ML. Consciência. In: Brandão ML. Psicofisiologia. $3^{\mathrm{a}}$ ed. São Paulo: Atheneu; 2012. p. 189.

23. Tart CT. Mediumship: experimental approach to postmortem survival. In: Tart CT. The end of materialism: how evidence of the paranormal is bringing science and spirit together. 1st ed. Oakland, California: New Harbinger Publications Inc.; 2009. p. 257-76.

24. Jinks T. The future of the field of mediumship. In: Rock AJ. The survival hypothesis: essays on mediumship. 1st ed. Jefferson, North Carolina: McFarland \& Company Inc.; 2013.

25. Roxburgh EC, Roe CA. A survey of dissociation, boundary-thinness and psychological wellbeing in spiritualist mental mediumship. J Parapsychol. 2011;75(2):279-99.

26. Moreira-Almeida A, Neto FL, Cardeña E. Comparison of Brazilian spiritist mediumship and dissociative identity disorder. J Nerv Ment Dis. $2008 ; 196(5): 420-4$.

27. Alminhana LO, Menezes Jr. A, Moreira-Almeida A. Personalidade, religiosidade e qualidade de vida em indivíduos que apresentam experiências anômalas em grupos religiosos. J Bras Psiquiatr. 2013;62(4):268-74.

28. Neri MC. Novo mapa das religiões. 1st ed. Rio de Janeiro: Fundação Getúlio Vargas/CPS; 2011.

29. Moreira-Almeida A. Fenomenologia das experiências mediúnicas, perfil e psicopatologia de médiuns espíritas [tese]. São Paulo: Universidade de São Paulo, Faculdade de Medicina, Departamento de Psiquiatria; 2004.

30. Beischel J, Schwartz GE. Anomalous information reception by research mediums demonstrated using a novel triple-blind protocol. Explore (NY). 2007;3(1):23-7.

31. Roy AE, Robertson TJ. Results of the application of the Robertson-Roy protocol to a series of experiments with mediums and participants. J Soc Psychical Res. 2004;68(1):161-74.

32. Schwartz GE, Geoffrion S, Jain S, Lewis S, Russek LG. Evidence of anomalous information retrieval between two mediums: replication in a double-blind design. J Soc Psych Res. 2003;67:115-30.

33. Kelly EW, Arcangel D. An investigation of mediums who claim to give information about deceased persons. J Nerv Ment Dis. 2011;199(1):11-7.

34. Beischel J, Boccuzzi M, Biuso M, Rock AJ. Anomalous information reception by research mediums under blinded conditions II: replication and extension. Explore (NY). 2015;11(2):136-42.

35. O'Keeffe C, Wiseman R. Testing alleged mediumship: methods and results. Br J Psychol. 2005;96(Pt 2):165-79.

36. Jensen CG, Cardeña E. A controlled long-distance test of a professional medium. Eur J Parapsychol. 2009;24(1):53-67.

37. Rocha AC, Paraná D, Freire ES, Lotufo Neto F, Moreira-Almeida A. Investigating the fit and accuracy of alleged mediumistic writing: a case study of Chico Xavier's letters. Explore (NY). 2014;10(5):300-8.

38. Kawai N, Honda M, Nakamura S, Samatra P, Sukardika K, Nakatani Y, et al. Catecholamines and opioid peptides increase in plasma in humans during possession trances. Neuroreport. 2001;12(16):3419-23.

39. Krippner S. Learning from the spirits: Candomblé, Umbanda, and Kardecismo in Recife, Brazil. Anthropology of Consciousness. 2008;19(1):1-32.

40. Oohashi T, Kawai N, Honda M, Nakamura S, Morimoto M, Nishina E, et al. Electroencephalographic measurement of possession trance in the field. Clin Neurophysiol. 2002;113(3):435-45.

41. Delorme A, Beischel J, Michel L, Boccuzzi M, Radin D, Mills PJ. Electrocortical activity associated with subjective communication with the deceased. Front Psychol. 2013;4:834.

42. Heller W, Nitschke JB, Etienne MA, Miller GA. Patterns of regional brain activity differentiate types of anxiety. J Abnorm Psychol. 1997;106(3):376-85.

43. Wallin BG, Esler M, Dorward P, Eisenhofer G, Ferrier C, Westerman $\mathrm{R}$, et al. Simultaneous measurements of cardiac noradrenaline spillover and sympathetic outflow to skeletal muscle in humans. J Physiol. 1992;453:45-58.
44. Hageman JJ, Peres JFP, Moreira-Almeida A, Caixeta L, Wickramasekera II I, Krippner S. The neurobiology of trance and mediumship in Brazil. In: Kripnner S, Friedman H. Mysterious minds: the neurobiology of psychics, mediums and other extraordinary people. Santa Barbara, CA: Praeger; 2010. p. 85-111.

45. Vanhaudenhuyse A, Laureys S, Faymonville ME. Neurophysiology of hypnosis. Neurophysiol Clin. 2014;44(4):343-53.

46. Deeley Q, Walsh E, Oakley DA, Bell V, Koppel C, Mehta MA, et al. Using hypnotic suggestion to model loss of control and awareness of movements: an exploratory FMRI study. PLoS One. 2013;8(10):e78324.

47. Deeley Q, Oakley DA, Walsh E, Bell V, Mehta MA, Halligan PW. Modelling psychiatric and cultural possession phenomena with suggestion and fMRI. Cortex. 2014;53:107-19.

48. During EH, Elahi FM, Taieb O, Moro MR, Baubet T. A critical review of dissociative trance and possession disorders: etiological, diagnostic, therapeutic, and nosological issues. Can J Psychiatry. 2011;56(4):235-42.

49. Littlewood R. Possession states. Psychiatry. 2004;3(8):8-10.

50. Beischel J. Contemporary methods used in laboratory-based mediumship research. J Parapsychol, 2007;71:37-68.

51. Beischel J. Advances in quantitative mediumship research. In: Rock AJ. The survival hypothesis: essays on mediumship. 1st ed. Jefferson, North Carolina: McFarland \& Company Inc.; 2013.

52. Peres JFP, Newberg A. Neuroimagem e mediunidade: uma promissora linha de pesquisa. Rev Psiquiatr Clin. 2013;40(6):225-32.

53. Sudduth M. Is postmortem survival the best explanation of the data of mediumship? In: Rock AJ. The survival hypothesis: essays on mediumship. 1st ed. Jefferson, North Carolina: McFarland \& Company Inc.; 2013.

54. Beischel J, Rock AJ. Adressing the survival versus psi debate through process-focused mediumship research. J Parapsychol. 2009;73:71-90.

55. O'Connor K. Towards a process paradigm in psychophysiology. Int J Psychophysiol. 1990;9:209-23.

56. Newberg AB. The neuroscientific study of spiritual practices. Front Psychol. 2014;5:215.

57. Rock AJ, Krippner S. States of consciousness redefined as patterns of phenomenal properties: an experimental application. In: Cvetkovic D, Cosic I. States of consciousness: experimental insights into meditation, waking, sleep and dreams. 1st ed. Berlin Heidelberg: Springer-Verlag; 2011. p. 264-5.

58. Pekala RJ. Quantifying consciousness: an empirical approach. 1st ed. New York: Plenum Press; 1991.

59. van Quekelberghe R, Altstotter-Gleich C, Hertweck E. Assessment schedule for altered states of consciousness: a brief report. J Parapsychol. 1991;55:37790.

60. Hartmann E, Ebldo R, Gargl M. Personality and dreaming : the dreams of people with very thick or very thin boundaries. Dreaming. 1991;1(4):311-24.

61. Tellegen A, Atkinson G. Openness to absorbing and self-altering experiences ("absorption"), a trait related to hypnotic susceptibility. J Abnorm Psychol. 1974;83(3):268-77.

62. Shor RE, Orne EC. Norms on the Harvard group scale of hypnotic susceptibility, form A. Int J Clin Exp Hypn. 1963;11:39-47.

63. Reiser EM, Schulter G, Weiss EM, Fink A, Rominger C, Papousek I. Decrease of prefrontal-posterior EEG coherence: loose control during social-emotional stimulation. Brain Cogn. 2012;80(1):144-54.

64. Passamonti L, Terracciano A, Riccelli R, Donzuso G, Cerasa A, Vaccaro $\mathrm{M}$, et al. A. Increased functional connectivity within mesocortical networks in open people. Neuroimage. 2015;104:301-9.

65. Lane RD, Waldstein SR, Chesney MA, Jennings JR, Lovallo WR, Kozel PJ, et al. The rebirth of neuroscience in psychosomatic medicine, Part I: historical context, methods, and relevant basic science. Psychosom Med. 2009;71(2):117-34.

66. Lane RD, McRae K, Reiman EM, Chen K, Ahern GL, Thayer JF. Neural correlates of heart rate variability during emotion. Neuroimage. 2009;44(1):213-22.

67. van der Kruijs SJ, Bodde NM, Carrette E, Lazeron RH, Vonck KE, Boon PA, et al. Neurophysiological correlates of dissociative symptoms. J Neurol Neurosurg Psychiatry. 2014;85(2):174-9.

68. Matsunaga M, Isowa T, Kimura K, Miyakoshi M, Kanayama N, Murakami H, et al. Associations among central nervous, endocrine, and immune activities when positive emotions are elicited by looking at a favorite person. Brain Behav Immun. 2008;22(3):408-17. 
69. Liou $\mathrm{CH}$, Hsieh CW, Hsieh $\mathrm{CH}$, Chen DY, Wang CH, Chen JH, et al. Detection of nighttime melatonin level in Chinese Original Quiet Sitting. J Formos Med Assoc. 2010;109(10):694-701.

70. Lucchetti G, Aguiar PR, Braghetta CC, Vallada CP, Moreira-Almeida A, Vallada H. Spiritist psychiatric hospitals in Brazil: integration of conventional psychiatric treatment and spiritual complementary therapy. Cult Med Psychiatry. 2012;36(1):124-35.
71. Lucchetti ALG. Descrição da terapia complementar religiosa em centros espíritas da cidade de São Paulo com ênfase na abordagem sobre problemas de saúde mental [dissertação]. São Paulo: Universidade de São Paulo, Faculdade de Medicina, Programa de Psiquiatria; 2013.

72. Hohmann AA, Richeport M, Marriott BM, Canino GJ, Rubio-Stipec M, Bird H. Spiritism in Puerto Rico. Results of an island-wide community study. Br J Psychiatry. 1990;156:328-35. 